This is a self-archived version of an original article. This version may differ from the original in pagination and typographic details.

Author(s): Palonen, Kari

Title: Four aspects of politics in Max Weber's Politik als Beruf

Year: 2019

Version: Accepted version (Final draft)

Copyright: @ 2019 SAGE Publications

Rights: In Copyright

Rights url: http://rightsstatements.org/page/lnC/1.0/?language=en

Please cite the original version:

Palonen, K. (2019). Four aspects of politics in Max Weber's Politik als Beruf. Journal of Classical Sociology, 19(4), 331-345. https://doi.org/10.1177/1468795X19851343 


\title{
Four aspects of politics in Max Weber's Politik als Beruf
}

Kari Palonen

University of Jyväskylä, Finland

\begin{abstract}
The article offers a rereading of Weber's Politik als Beruf as a conceptualization of politics contingent and controversial activity in terms the four aspects of politics: politicisation, polity, politicking and policy. Weber discusses politics as a concept abstracted from its content. All four aspects can be found in his exposition of the concept. Weber mentions first policy as the direction of politics and demarcates his focus on the state-type polities. Then he presents the formula on politics as striving for power, consisting of chances to politicise its distinct shares, and discusses historical types of professional politicians and their styles of politicking. Weber illustrates the opposition between independent politicking and its result as a policy that the officials must execute. His triad passion for a cause, sense of responsibility and detached judgement among politicians corresponds to the references to politicking, polity and politicisation, whereas the ethic of responsibility refers to situational politicking, but the ethic of conviction to a strict policy, which in some cases contains chances to politicise the situation. Weber's final metaphor of politics as slow and patient drilling of hard board can be read in a way containing all the four aspects of politics.
\end{abstract}

Keywords: Max Weber, Politik as Beruf, politics as an activity, conceptual history, politicisation, politicking, polity, policy

Introduction

In textbooks and introductory works to political science several formulations from Politik als Beruf have been presented as the 'Weberian conception of politics'. In my commentary, Eine Lobrede für Politiker from 2002, I directed attention to this multiplicity of quasi-definitions and explications of politics in Weber's booklet. I insisted on taking all those formulae into account and claimed that Politik als Beruf contains a narrative that deals with the multiple aspects of politics.

From a distance of several years, I now return to the Weberian formulae and suggest that they can be better interconnected than what I thought in the Lobrede. As a medium for doing that I shall use the analytical scheme for the activity-concept of politics, sketched in the article 'Four Times of Politics' (Palonen 2003). I modified the common triad of the English word referring to the adjective 'political' - politics, policy and polity (as used for example by Rohe, 1978/1994) - by dividing 'politics' to the activities of 
politicisation and politicking. I thus understand the activity of 'politics' as consisting of four aspects: politicisation, politicking, polity, policy. I summarised the relationships between the four aspects of politics in the conclusion of the 2003 article as follows:

Politics, as presented here, is understood as a correlate between two activities, politicisation and politicking, while polity and policy refer to their 'regulating' limit-situations. Politicisation searches for new power shares, while politicking aims at an increase in disposition over the existing ones. Agents making use of either of these performatives refer to the other one as well as to the past and future variants of the same operation. This reference indicates temporal discrepancies, highlighting chances of revision while simultaneously constituting a new relative continuity in time between historical forms of both politicking and politicisation. (Palonen, 2003: 186; also Palonen, 2017: 28).

The scheme might offer a distancing effect for identifying the multiple aspects of politics in Weber's vocabulary. With this way of reading the genre of Politik als Beruf is not only an eulogy for the professional politician - as I claim in my 2002 book title - but contains a draft to discussing a more comprehensive account of the main aspects of politics than what has been commonly understood. This article is a thought experiment that aims at spelling out distinct chances included in Weber's formulae by reading the text in terms of the scheme of four aspects of politics.

At the same I want to emphasise the stylistic difference between Politik als Beruf, based on a public lecture, and the lexical genre of the first part of Wirtschaft und Gesellschaft (Weber, 1922). This can be seen how Weber poses the question. He does not declare 'Politik soll heißen' but asks, 'Was verstehen wir unter Politik?' (Weber, 1919a: $35)^{1}$ ? For Weber in Politik als Beruf this question almost equals what politicians are typically doing. In other words, he analyses the activity of politics mainly through the ideal types of the politician.

A formal discussion of politics as a concept

Weber's booklet consists of a widely extended version of his lecture in Munich 28 January 1919, published in July the same year. He begins with a remark that he will disappoint the expectations of the public by not saying anything to the current affairs (aktuelle Tagesfragen), except discussing at the end the formal significance of doing 
politics, 'Bedeutung des politischen Tuns innerhalb der gesamten Lebenführung'2 (ibid). Even more strange for the audience might seem Weber's decision to bracket the question of the content of politics or policy: 'Ganz ausgeschaltet werden müssen ... alle Fragen, ... welche Politik man treiben, welche Inhalte ... man seinem politischen Tun geben soll'3(ibid.).

These demarcations seem to have an educative intention towards the predominantly student audience. Weber wants them to learn that it is possible and important to regard Politik as a concept independently of its content and direction, to think of politics as a formal category that covers different content and styles of doing politics. This was at that time in the German context still a rare way of thinking of politics as action (Handeln).

Weber's formal view deviates from the lectures by the nineteenth century historians, for which Politik still was a broad summary title of various phenomena rather than a distinctive quality of human activity (see the Politik lectures of Heinrich v. Treitschke, published posthumously in 1897). A new kind of discussion of the concept was, however. arising at the turn of the century, for example in Albert Schäffle's article (1897), in the new Zeitschrift für Politik, including the programmatic article by Richard Schmidt (1907) as well as in the Politik articles of Rehm and Zürn in Handbuch der Politik (1913) (see Palonen, 1985 and 2006). Although Weber does not comment these views, Politik als Beruf can be regarded as a contribution to this debate on conceptualising politics in formal terms, although in a way that resets the agenda for further debates.

Politics as directive activity

The first politics-formula that Weber offers to the readers of Politik als Beruf refers to the action of independent directing, 'umfaßt jede Art selbständig leitender Tätigkeit' ${ }^{4}$ (Weber, 1919a: 35). This formulation alludes to the polity, over which the political actor is exercising 'leadership', as well as to the policy, which consists in the coordination of the action in a way that it gives to it a definite direction.

In the following sentences Weber explicitly focuses on the policy aspect. He mentions for example the 'Devisenpolitik der Banken'5 or the 'Politik einer klugen Frau, die ihren Mann zu lenken trachtet' ${ }^{6}$, an expression borrowed from Werner Sombart (ibid. see Palonen, 2017: 44). Weber, however, notices that 'heute', that is, in his lecture, he will 
not say more on this policy aspect.

Nonetheless, Weber considers the policy-vocabulary as a legitimate way of referring to 'our understanding of politics', independently of the level of the polity in question. He is also ready to include the two-person relationships, such as marriage, among the polities. Also in a letter to Robert Michels on 31 December 1910, in which Weber criticised Michels's 'too simple' concept of Herrschaft, we can see that he recognised the presence of the rulership aspect in private life, including marriage (Weber, 1994a: 761).

Weber further limits his discussion in Politik als Beruf to politics within a polity, politischer Verband, that is in practice, within the state or to the relationships between the states (Weber, 1919a: 35). Here we should remember that for Weber - as opposed to vulgarisations of his views in textbooks of international relations studies - the state never is an 'acting subject' but rather a type of Chance complex, which includes certain and excludes other ways of acting politically (Weber, 1922: 6 and his last lectures, Weber, 2009, see also Palonen, 2011). The state-bound framing of Politik als Beruf is no normative choice but merely an expression of the historical situation of his time. To analyse its internal power struggles in a supra-national polity, such as the European Union, would not have presented to Weber any greater difficulties.

In Politik als Beruf Weber thus merely makes a demarcation that he deals with politics as action (Handeln) within the state-type of polities, for which the means of physical violence (Gewaltsamkeit) serve as the decisive criterion. He does not speak of politics in the cities or in the universities. However, inside this polity-type Weber is focusing on the internal qualities and requirements of the activity of politics as illustrated by the historical types of professional politicians. This discussion could, mutatis mutandis, applied to other polity levels.

Politics as striving for power

Weber's best-known formulation for politics is: 'Streben nach Machtanteil und Beeinflußung der Machtverteilung'7 . A few lines later he presents a shorter formula: 'Wer Politik treibt, erstrebt Macht'” (Weber, 1919: 36, see also 41).

Despite his clear declaration, it is seldom properly understood that for Weber Macht is no 
given entity or relationship but consists of Chancen to act in relation to others: 'Macht bedeutet jede Chance, innerhalb einer sozialen Beziehung den eigenen Willen auch gegen Widerstreben durchzusetzen"9 (Weber, 1922: 28). It is the Chance that opens up some possibilities to act. Weber leaves open how to use these chances - and here I am using the English word in Weber's sense of Chance. For him Macht is independent of its sources, 'gleichviel worauf diese Chance beruht' ${ }^{10}$ (ibid.). The identification of the chances politicises the 'relationship' in question, marks it as contingent and 'playable' for the actors. In this sense Streben and Machtstreben can be identified as intending to politicise an issue by turning it into a source of power, Machtanteil.

Furthermore, for the nominalist Weber Macht consists of separate Anteile and their distribution. He leaves open what can serve as a source of power in each situation. The translation 'shares of power' does not clearly distinguish between the egalitarian Anteile and the non-egalitarian Aktien on the stock market. Weber with his language of Anteile and their distribution refers to the specific power profile of the polity, in which the actors strive to alter the current distribution. This striving for redistributing power shares marks an act of politicking, dealing with the available chances to use power, although it can also open up further politicising chances, by intention or as a by-product.

When Weber criticises the striving for power as an end in itself - 'um ihrer selbst willen' (Weber. 1919a: 36) -, he illustrates that politicising a question by the creation or identification of some Chancen is only a condition for politicking. He then expects it to be followed by choosing some ways to act with these chances in relation to the action of others. Competent politicians make use of the available chances for action to the purposes they choose as worth striving for, independently of how they have become politicised.

To choose one's own 'will', refers to the chosen substantial aims and to politicking in favour of their realisation against the expected striving against (Widerstreben) among the concerned persons. Weber leaves it up to the actors themselves to decide upon the aims worth striving for, consciously avoiding to give any advice. Widerstreben recognises the adversaries as expected and legitimate political opponents to any striving for power. The procedure of parliamentary debating can be seen as the ideal typical fair occasion for politicking by means of deliberating pro et contra on the uses of Machtchancen and deciding upon policies by counting the votes (Weber, 1917b, 1918, see Palonen, 2010; 
2018).

Also in reading Politik als Beruf we should take into account a central paragraph in the beginning of Weber's 'Objektivität' essay that provides a key for how the political ends and means (Zwecke und Mittel) should be chosen (Weber, 1904: 149-150). For Weber ends and means cannot be decided independently of the situation. On the contrary, their choice depends on judging the horizon of Chancen available in the situation as well as the expected Nebenfolgen of alternative actions, their 'side-effects' or 'by-products' that by no means are a secondary part of the situation.

As for judging the horizon of Chancen, Weber was since his youth critical of Realpolitik. In the 'Wertfreiheit' essay he explicitly regards politics as 'the art of the impossible', Kunst des Unmöglichen (Weber, 1917a: 514). He realises that nobody will reach the best possible out of a situation without striving for something beyond the surely and immediately possible, as the language of Realpolitik since Rochau (1853/1869) was content to do. In a passage of Politik als Beruf Weber also regards the regular (regelmäßig) presence of unintended consequences as characteristics for politics (Weber, 1919a: 75-76). A politician must cope with their occurrence, without being able to estimate their exact content. This complex of chances, ends, means and side effects distinguishes Weber from simple means-ends-thinkers. It is clear that for him these dimensions of the situation are a matter of interpretation and debate among the participants, according to the procedural model included in the 'Objektivität' essay (see the discussion in Palonen, 2010 and chapters 10 to 12 in Palonen, 2017).

\section{Historical types of politicians}

The activity of the professional politicians, "Politiker kraft "Berufes" in des Wortes eigentlichster Bedeutung ${ }^{11}$ (Weber, 1919a: 38), offers to Weber the closest approximation of the ideal type of acting politically. He distinguishes, following James Bryce (1888/1914), two types of professional politicians, those 'living of politics' and those 'living for politics' (ibid.: 42, see already Weber, 1905). In Weber's time it was still possible for some persons with independent means to live purely 'for politics'. Today practically every important politician must also live off politics, even if some multimillionaires now and then try their luck 'in politics', although remaining reluctant to 
see themselves as professional politicians.

The largest part of Politik als Beruf deals with historical types of the professional politicians, especially the modern ones: the party boss, the election agent, the advocate and the journalist (Weber, 1919a: 42-73). In addition, Weber intensely discusses the professional parliamentarian in his Parlament pamphlet (Weber, 1918: 244-248, 262267), the absence of which from Politik als Beruf might give a misleading picture of Weber's views on politicians (see Palonen, 2017: 61-68). In these sections there are less conceptual discussions, and the actors are focusing mainly on politicking, of acting within the existing horizon of chances of a given polity. Those 'tüchtige Männer' 12 (Weber, 1919a: 68) who have been elected presidents of the United States are the exception. They identify themselves with representing the polity, which the politicians living purely off politics do not properly care for.

In a remark on the advocate and the journalist as good examples of contemporary politicians, Weber insists on the increasingly verbal character of politics: 'die heutige Politik wird ... in hervorragendem Maße ... mit den Mittel des gesprochenen oder geschriebenen Wortes geführt' ${ }^{\prime 3}$ (Weber, 1919a: 53). Thus, although the state-type polities are constituted by the legitimate violence, the actual politicking in Western states is above all a rhetorical activity of formulating, supporting, criticising and revising policies.

The typical activities of citizens, who engage themselves as occasional politicians ('Gelegenheits 'politiker, Weber, 1919a: 41) also correspond to politicking. Nonetheless, this type of politician could have better chances to politicise new questions to the agenda than the professional politicians as insiders of the polity. Politicisation requires a certain distance to the busy routine concerns of politicians living off politics, who must take as given what is possible and legitimate within the polity. The leading politicians living for politics could also have chances to politicise new types of questions to the agenda of debates, because they, unlike the local bosses or functionaries living off politics, might face new and unexpected situations that include changes to agenda or invite to unconventional forms of doing politics.

The condition of the professional politician 
A major topic in Politik als Beruf lies in the distinction between the politician and the official. In the typological sense also the official - 'Der echte Beamte' ${ }^{14}$ (Weber, 1919a: 53) - acts politically, but only by interpreting and executing policies that have already been chosen in the struggle between politicians with independent responsibility. From Weber's perspective politicking should not be allowed to officials, but only for those who exercise political judgement dealing with contingent situations.

When contrasted with the official, the activities of a politician are presented by Weber as 'Parteinahme, Kampf, Leidenschaft' ${ }^{15}$ (ibid.). The contingency of a politician's action is marked by facing opposed stands in debate, the presence of adversaries and passionate struggles with them. This is the very core of politicking, dealing with issues already on the agenda, although politicising moves - new motions or amendments to motions in the parliamentary sense - might be introduced as major moves in this struggle that challenge the current agenda. Today, the struggles over agenda-setting have gained a greater political weight in the profile of politicians than in Weber's time, and in this sense at least politicians living for politics must be ready and willing to politicise new issues.

When Weber moves to discussing the criteria required from the professional politicians, in particular those living for politics, he sets a necessary condition for becoming a professional politician. This condition is the feeling for power, Machtgefühl, 'das Gefühl, einen Nervenstrang historisch wichtigen Geschehens mit in Händen zu halten"16 (Weber, 1919a: 73). It refers to a politician's competence and willingness to deal with the chances of different shares of power, not only in the sense of politicking in favour of some ends or opposing the projects of adversaries. The sense for power also presupposes a capacity to identify the chances to power on any issues, that is, chances for their politicisation by means of composing or identifying new Machtanteile in the situation.

A counter-concept to Machtgefühl, which might not always be easy to separate from it, lies in a temptation, namely in the Eitelkeit, vanity. Weber strongly demands politicians to resist it as 'die Todfeindin aller sachlichen Hingabe und ...der Distanz sich selbst gegenüber' ${ }^{17}$ (ibid.: 74). Due to vanity, a politician might be liable to miss chances of politicisation of questions, sacrificing them in favour of personal power shares. In other words, a politician is tempted to set the reputation or celebrity of the person into the 
focus of her action at the cost of opening up something new to the agenda of debates.

For Weber vanity leads to unsachlich forms of striving for power, to the chances that are misdirected away from the chosen Sache, directing politics towards 'rein persönlicher Selbstberauschung' ${ }^{18}$ (ibid.: 75 ). Weber sees such politicians in the danger of becoming Schauspieler, play-actors in the scene of a theatre. The mere Machtpolitiker, for whom the power is an end in itself remains empty and without effect on policies (ibid.: 74-75).

However, we can ask, whether this view is, after all, compatible with Weber's formal Chance-based concept of Macht, for which the danger lies rather in not being able or willing to choose between the available chances. Some contemporary scholars argue against Weber that today, in the 'media-age', vanity is an inherent part of politicking itself (Eckert, Nowy and Schwickert, 2013: 23), namely in turning one's own personality into a power share, to use Weber's terms. In this sense politicians want to adapt to the existing polity at the cost of rejecting their powers to politicise questions. When Max Weber, the theorist of charismatic politicians, rejects vanity as a lack of distance to does this not unduly simplify a politician's repertoire?

Weber's view of politics has from early on been criticised as being too 'serious', not ready to play, as already Helmuth Plessner remarked (1924: 22, see also Jaspers 1962, to Plessner's view see also Steinmetz 2012: 113-114). To some extent, a politician has to act as if she would be on stage, not revealing her 'true personality' but presenting multiple facets of oneself, also in order to increase one's repertoire for politicking. The politicisation of one's own person, in the sense of detecting different power shares within it, might be an aspect of charisma, which Weber did not thematise. This view would corresponds to his view that charisma is not a personal quality of the politician but a rhetorical relationship to the audience, as in his discussion of the anti-authoritarian reinterpretation of the charisma of elected politicians (see Weber, 1922: 155-157).

Passion, sense of responsibility and approximate judgement As decisive qualities - or qualification criteria - for a politician Weber presents his wellknown triad: 'Leidenschaft - Verantwortungsgefühl - Augenmaß'19 (Weber, 1919a: 7374). The expressions require explication, which Weber also offers in Politik als Beruf. 
Above all 'passion' does not refer to any emotions, but rather to the dedicated commitment to a cause, "leidenschaftliche Hingabe an eine "Sache"' (ibid.: 74) ${ }^{20}$. Among Weber's most difficult concepts to translate are Sache and Sachlichkeit. In this context Sache does not refer to any 'thing' or 'phenomenon', not to 'objectivity' or 'matter-offactness' but to the normative 'cause', to the chosen direction of a policy. The 'commitment' refers to the self-chosen rigidity of the policy, as contrasted with the 'opportunistic' adaptation to the situation, to the dimension of Wertrationalität as contrasted with the Zweckrationalität.

Weber links Sachlichkeit also with Verantwortungsgefühl and Verantwortlichkeit. Here he is more concerned with the fate of the polity, in a way for which Weber in his early work used the term Staatsräson (see Weber, 1895). Weber expects from politicians to care for the consequences of their politicking and policies for the polity. From early on, one major point in Weber's writings on German politics was the critique of Bismarck's irresponsible neglect of the political education of the citizens, which contributed to maintaining a polity without a government responsible to parliament (see esp. Weber, 1918: 205-212). The parliamentary dimension is built into the Verantwortungsgefühl, as presented in Politik als Beruf, and the Westminster-style responsibility of the government to parliament was maintained also in the context of Weber's support for the directly elected Reichspräsident (Weber, 1919b).

One of Weber's typical rhetorical moves was to turn concepts borrowed from others to his own purposes, eventually opposing previous users. As scholars of German politics and history know, Augenmaß was a key expression in Otto v. Bismarck's political language (see for example Bismarck, 1898: 324). Weber shares with Bismarck the literary meaning of the concept, in emphasising that in politics there are inherent limits to exact measurement, and therefore an approximate judgement, for which the 'measuring by eyes' is an excellent metaphor, is indispensable.

Much less sure is that Bismarck would have subscribed to Weber's interpretation of his distinct point with Augenmaß, namely 'die Fähigkeit ... der Distanz zu den Dingen und Menschen' (Weber, 1919a: 74) ${ }^{21}$. In other words, judgement is not only approximate but also detached. Lack of distance marks for Weber the lack of willingness or competence to judge questions politically, with a view to the chances and unintended 
consequences involved in them. To speak of distance to things and human beings refers to the possibility to politicise items and politick with them, as a criterion that shall not be sacrificed to any policy cause. This is another consequence of the priority of politicising, that is, striving for new power chances over the question what to do with the available power shares, although politicking with available shares is also necessary.

Weber does not with his triad accept a 'division of labour' between three types of politicians. There cannot be passionate, responsible and detached types of politicians, but a politician must attempt to be all that at the same time, although knowing that it is an art of the impossible: 'das Problem ist eben: wie heiße Leidenschaft und kühles Augenmaß miteinander in derselben Seele zusammengezwungen werden können' (ibid.) ${ }^{22}$. How to do that, Weber again leaves to each politician the burden of choosing without giving any advice how their compatibility might be approached and which kind of effects it might have.

The two ethics of the politician

The next step in Weber's conceptualisation of politics through the activity of the politician deals with the "ethos der Politik als "Sache""23 (Weber, 1919a: 76)? The relationship of politics to morals played a prominent role in the disputes concerning the Bismarckian Realpolitik. Roughly speaking, with Treitschke one side denied that politics has anything to do with ethics, whereas many liberal opponents tended to require following same norms in politics as in private life. During First World War this debate was once again activated, and Weber's discussion must be read against this background (see Palonen 1985, 88-94).

Weber's turn in the debate consists of discussing a special ethic for the politician, 'der ethische Ort' ${ }^{\text {'4 }}$ (Weber. 1919a: 76) - as an inherent part of conceptualising politics. Weber denounces the on-going debate on the war-guilt as past-oriented and as such irrelevant for the ethic of the politician (ibid.: 76-77). From today's perspective this way of avoiding the question of guilt illustrates that the questions discussed today under the heading 'the politics of the past' did not yet concern the Weberian ideal type of politician.

As we know, Weber presents two opposite 'maxims', 'gesinnungsethisch' or 'verantwortungsethisch' ${ }^{25}$ (ibid.: 79). This is perhaps the most disputed contrast of Politik 
als Beruf, and a closer look at the formulations is required. The ethic of conviction is based on certain normative maxims, whereas the ethic of responsibility discusses and evaluates the consequences of politics, at this point Weber even requires them to be foreseeable (voraussehbar, ibid).

Weber's paradigmatic adherent to the ethic of conviction is the syndicalist, an important figure in the early twentieth-century left-wing and trade union politics. In Weber's view the syndicalists are not concerned with the foreseeable consequences of actions, it is not the actor but the world itself which is responsible for them (ibid.: 80). Only the choice of maxims counts for them or other Gesinnungsethiker, whereas the contingency of Nebenfolgen is seen as a secondary or even an irrelevant question.

For Weber the Verantwortungsethiker have a different worldview. They insist that human beings in the average have their weaknesses, which must be considered in judging the consequences. However, they do not blame them for that but recognise that if they themselves discard this quality of human beings - die Art des Menschentums, as Wilhelm Hennis (1987) emphasises in his Weber interpretation - they must take the contingency of the unwanted consequences to their own account (Weber, 1919a: 80). In typological terms, the ethics of conviction is committed to a rigid policy against 'opportunistic' politicking, whereas the ethic of responsibility requires experimental forms of politicking in order to be able to discuss the consequences.

The question of ends and means reappears for both types of ethics, but Weber's point is that there is no general principle for deciding over the acceptability of consequences. The use of legitimate violence is, of course, the key point in the controversy, combined with the insight that 'alliance with diabolic powers' is frequently necessary for a politician. Those who do not recognise that are for Weber 'political children' (ibid. 82). The willingness to accept that the resort to violence as the last means of politics marks the setting of the fate of the polity over the conviction of individual 'believers', whether religious or revolutionary.

Nonetheless, Weber shows respect for radical-pacifist sects, such as the Quakers in Pennsylvania, although see them doomed in advance in the US civil war (ibid.: 83). It is possible to identify within pacifist movements ways of politicisation, challenging the established order of the states and indicating possible chances to reduce the degree of 
violence. In contrast to the pedagogy professor F.W. Foerster, whom Weber criticises (ibid.: 81, 83), more political forms of pacifism entered the debate after the war, in the Weimar republic for example Kurt Hiller's ‘Gruppe revolutionärer Pazifisten' (see a selection of Hiller's pacifist writings in Reinhardt, 1983). More recently such thinkers as Johan Galtung or Gene Sharp have presented strategies of non-violent resistance. They have identified in pacifist practices chances of politicisation and politicking that Weber still was not ready or willing to see (cp. Sharp, 1964 on Weber).

Parallel to what Weber said on the necessary combination of the three qualifications of the politician, so impossible it might be, he insists on the necessity for a politician to face and bear himself 'ethical paradoxes' (Weber, 1919a: 85). They are built into the polity itself, and a politician is challenged to deal with the ethos in terms of judging and weighting these paradoxes, that is, to politick with ethics as a dimension of the polity, even of politicisation (cp. Sartre, 1991, written in mid-1960s).

Once again Weber merely sets the agenda for the debate on the two ethics, but leaves the choice to the actors in the situation: 'Ob man aber als Gesinnungsethiker oder als Verantwortungsethiker handeln soll, und wann das eine und das andere, darüber kann man niemandem Vorschriften machen. ${ }^{26}$ (Weber, 1919a: 86) Competent politicians can be only persons, who master the repertoire of both ethics and recognise that they is obliged to judge their strengths and weaknesses according to each situation. In this sense we could say that in the 'ethos polity' à la Weber it is politicking and not a rigid policy that is required.

In his own time Weber tended to regard the consequences of the Gesinnungsethik to be more severe, but he recognises that a point can arrive in which it is politically significant to hold fast to one's Gesinnung, as a sign of personal maturity. He admits that politics will not be alone done with the head but also emotions are always part of the game (ibid.), and they might set limits to the 'opportunistic' adaptation to the foreseeable consequences. In so far as a rigid policy might in certain cases not only mark a chance to politicise the question but also be the wisest form of politicking.

At the end of the lecture Weber presents a pessimistic prognosis for the next ten years as a wave of the reaction, 'eine Polarnacht von eisiger Finsternis und Härte'27 (ibid.: 88). Only those have the Beruf of a politician who will admit that the contingency of the 
world events might also result in dark or horrible consequences. A politician worth that name can be only someone who is willing to face such a situation and does not lose her judgement and competence to politick even in such situation. Now we know that the polar night that began 14 years after Weber's lecture widely transcended even his pessimistic views and challenged the chances to act politically at all.

Politics as a slow drilling of hard boards

The final formula for understanding the activity of politics in Politik als Beruf then consists of Weber's famous metaphor: 'Die Politik bedeutet ein starkes langsames Bohren von harten Brettern mit Leidenschaft und Augenmaß zugleich'28 (ibid.: 88). This metaphor has hardly found its way into political science textbooks, but when looking at Weber references in parliamentary debates, I found that this is the favourite quote of the parliamentarians. This holds in particular for the German Bundestag and the Austrian Nationalrat, but also in other West European parliaments we can find it occasionally quoted (see Palonen forthcoming 2019: chapter 13). In the following analysis I also use some of the innovative and though-provoking interpretations among the MPs to situate the formula to my scheme.

Indeed, this picture of a politician's activities might be illustrative for political agents precisely because all four aspects can be read out of it. The activity of hard and slow drilling is first of all understandable as a patient and tenacious politicking in the face of a persistent opposition. In the parliamentary debates there are different interpretations, whether the hard boards refer to the opposing actors and their resistance or whether drilling has been practised from opposite directions. A competition of drillings to the same direction would be a metaphor for policies, choosing different lines to proceed but competing in who will be the fastest to reach a breakthrough or who does the least damage to the boards.

At the same time the very point of drilling is to make a hole, a 'breakthrough', that is, new chances for acting beyond the boards. This moment of opening marks a politicisation that creates new chances for politicking. In this interpretation the boards refer to the existing polity that contains obstacles to a politicising breakthrough outside them, which would no longer restrict the legitimate polity to the range of the boards. Politicisation is, 
however, efficient only if it does not destroy the boards but retains as much as possible of the forms of politicking allowed within the polity. Similarly to the competing styles of politicking or foci of policies we could distinguish in the situation different angles of politicisation, and nobody can be sure who will achieve a breakthrough or which types of chances each of the breakthroughs opens and closes.

Max Weber's artisan metaphor remains intelligible today and allows different perspectives on interpreting the activity of politics and of professional politicians in particular. The metaphor with its emphasis on patient and artisan competence also illustrates, how occasional or amateur politicians hardly would have any realistic chances as actors drilling the boards, and political dilettantes or illiterates do not have any idea of the hardness of the situation of politicians.

The example might also inspire us to invent and construct second-level metaphors, in which the drilling and the boards could be replaced with different types of procedures and strategies in the face of obstacles and resistances that the politicians should be ready and willing to encounter and deal with. We could for example use Weber's example as analogies to those difficulties that we meet when trying to orient ourselves in the digital world, not as technicians of that world, but as politicians exploring the chances and unintended consequences of operating in and with the digital world.

\section{A Weberian type of political imagination}

To sum up, the four aspects of my scheme of politics are all present in Politik als Beruf and interconnected with each other, provided one is willing to speculate with the interpretative possibilities of the formulations and to imagine the situation of persons doing politics with them. This reading of Weber indicates the heuristic value of the scheme for analysing the internal connections between different aspects of politics. In contrast, separating them from the conceptual cluster of politics, for example in the policy-analysis or in the recent debates on politicisation around the EU (for a comment see Kauppi and Wiesner, 2018), is hardly convincing.

Weber's own view of what politicians do or can do was, of course, bound with the conventions of his time in a way that for example Quentin Skinner (1970) has discussed, that is, including the chances of their revision or subversion. Today we have learnt to 
speculate with ways of doing politics that he still excluded or ignored. When Weber in Wissenschaft als Beruf sets the ideal that the present state of knowledge will soon be outdated (Weber, 1919c: 8), these examples illustrate just this state of affairs. At the same time the Weberian way of acting, thinking, judging and imagining politically has by no means become obsolete. On the contrary, more than some decades ago, Weber is a major name on the agenda of both scholars and politicians.

In looking for the parliamentary uses of 'Max Weber' I was struck by a notable absence: no parliamentarian in the parliaments consulted referred to Weber's formula of politics as striving for power. The very idea might look too trivial: there is no need to quote Weber to say that. Nonetheless, remembering that Macht, as all Weberian concepts, especially those discussed in the newer part of Wirtschaft und Gesellschaft, is a Chance concept, I see in striving for power the nucleus of Weber's conceptualisation of politics as a politicising activity, through which the other expressions might be better understood.

In the everyday speaking of 'power politics' or 'struggle for power', the concept is taken as being unproblematic, almost a fact, and that holds also for the textbook view on so-called 'realist' theories of international politics (as opposed to the original texts that have later attributed this epithet, such as Carr, 1939 and Morgenthau, 1948). In contrast, the Weberian view of power as a Chance concept refers to the insight that for an acting politician that what is possible - the occasion, opportunity or situation to do something -, using the actual to some specific purpose, enjoys a conceptual priority.

This priority of Machtchancen also makes it intelligible that when understanding politics as an activity, politicisation is no extension of the margins of the political. On the contrary, politicisation is the primary move of marking, constituting something as political. Politicisation renders politicking, polity and policy possible.

With Weber's concept of Machtchance we can crystallise the four aspects of politics as activity. Politicisation marks identification and creation of chances, polity contains the current range of legitimate chances, politicking consists playing with the available chances and policy excludes those chances that prevent action to a definite direction. 
1 'What do we understand by politics' (Politik)? (Weber, 1994b: 309).

2 'The significance of political action within our conduct of life as a whole' (ibid.).

3 'What must be completely excluded ... are question of which brand of politics one ought to practise, ... the content one ought to give one's political activity (ibid.).

4 'The term is embracing ... every kind of independent leadership (leitende) activity' (ibid.).

5 'The banks' policy of foreign exchange' (ibid.: 310 ).

6 'The policies of an astute wife in her efforts to guide her husband' (ibid.).

7 'striving for a share of power or for influence on the distribution of power' (ibid.: 311).

8 'Anyone engaged in politics is striving for power' (ibid.).

9 'Power (Macht) can be defined as the chance, within a social relationship, of enforcing one's will against resistance'(Weber, 2004: 355).

10 'whatever this chance might be based on' (Weber, 1994b: 311)

11 'politicians by virtue of a "vocation", in the truest sense of the word' (ibid.: 313)

12 'able men' (ibid.: 347).

13 'politics is nowadays predominantly conducted ... by means of the written or spoken word' (ibid.: 330).

14 'the true official' (ibid.)

15 'partisanship, fighting, passion' (ibid.).

16 'the knowledge that he holds in his hands some vital strand of historically important events' (ibid.: 352).

17 'the mortal enemy of all dedication to a cause and of all distance - in this case of distance to oneself' (ibid.: 353).

18 'a matter of purely personal self-intoxication' (ibid.: 354).

19 'passion, a sense of responsibility, judgement' (ibid.: 352).

20 “'ability to maintain ... distance from things and people' (ibid.: 353)

21 'the passionate commitment to a "cause" (Sache)' (ibid.).

22 'how are hot passion and cool judgement to forced together in a single soul?' (ibid.)

23 'the ethos of politics as a 'cause' (Sache)' (ibid.: 355).

24 'the ethical home of politics' (ibid.).

25 “"the ethic of principled conviction" (Gesinnung) and "the ethic of responsibility"” (ibid.: 359).

26 'But whether one ought to act on the basis of the ethic of conviction or one of responsibility, and when one should do the one or the other, there are not things about which one can give instructions to anybody.' (ibid.: 367).

27 'a polar night of icy darkness' (ibid.: 368).

28 'Politics means slow, strong drilling through hard boards, with a combination of passion and a sense of judgement' (ibid,: 369). 


\section{References}

Bismarck, O. v. (1898) Gedanken und Erinnerungen. http://www.zeno.org/Geschichte/M/Bismarck,+Otto+von/Gedanken+und+Erinnerung en

Bryce, J. (1888/1914 [1995]). The American Commonwealth. Indianapolis: Liberty Fund. Carr, E. H. 1939 [1961]. The Twenty-Years Crisis 1919-1939. London: Macmillan.

Eckert, G., Nowy, L., Schwickert D. (2013) Erfolgreiche Politik! Zwischen Macht und Ohnmacht - eine Einleitung. In: G. Eckert, L. Nowy. D. Schwickert (eds) Zwischen Macht und Ohnmacht. Wiesbaden: Springer/VS. 11-30.

Hennis, W. (1987) Max Webers Fragestellung. Tübingen: Mohr.

Jaspers, K. (1962 [1988]) Bemerkungen zu Max Webers politischem Denken. In: Karl Jaspers, Max Weber. Gesammelte Schriften, 115-127. München: Piper.

Kauppi, N., Wiesner C. (2018) Exit Politics, Enter Politicisation?, Journal of European Integration, 227-233.

Morgenthau, H. J. (1948) Politics Among Nations. New York: Knopf.

Palonen, K. (1985) Politik als Handlungsbegriff. Horizontwandel des Politikbegriffs in Deutschland 1890-1933, Helsinki: Societas Scientiarum Fennica

Palonen, K. (2002) Eine Lobrede für Politiker. Kommentar zu Max Webers 'Politik als Beruf. Opladen: Leske+Budrich.

Palonen, K. (2003) Four Times of Politics: Policy, Polity, Politicking and Politicization. Alternatives 38, 2003, 171-186

Palonen, K. (2006) The Struggle with Time. A conceptual history of 'politics' as an activity, Münster: LIT.

Palonen, K. (2010) „Objektivität“ als faires Spiel. Wissenschaft als Politik bei Max Weber, Baden-Baden: Nomos.

Palonen, K. (2017) The State as a Chance Concept: Max Weber's desubstantialization and neutralization of a concept. Max Weber Studies 11, 2011, 99-117.

Palonen, K. (2017) A Political Style of Thinking. Essays on Max Weber. Colchester: ECPR Press.

Palonen, K. (2018) Parliamentary Thinking. Procedure, Rhetoric and Time. London: Palgrave Macmillan.

Palonen, K. (2019, forthcoming) Max Webers Begriffspolitik. Aufsätze aus zwei Jahrzehnten. Baden-Baden: Nomos

Plessner, H. (1924 [1981]) Die Grenzen der Gemeinschaft. In: Gesammelte Schriften V. Frankfurt/M: Suhrkamp.

Rehm, H. (1913) Politik als Wissenschaft - ihre Zweige. In: Handbuch der Politik, Bd. I. Berlin: Rotschild, 7-11.

Reinhardt, S. (1983) Kurt Hiller. Politische Publizistik von 1918-1933. Heidelberg: Wunderhorn.

Rochau, L.A. von (1853/1869 [1972]) Grundsätze der Realpolitik. Frankfurt/M.: Ullstein.

Rohe, K. 1978/1994. Politik. Begriffe und Wirklichkeiten. Stuttgart: Kohlhammer.

Sartre, J.-P. (1991) Kennedy and West Virginia. In: Sartre alive, ed. Ronald Aronson and Adrian van den Hoven. Detroit: Wayne State University Press, 37-52.

Schäffle, A. (1897) Über den wissenschaftlichen Begriff der Politik, Zeitschrift für die gesamte Staatswissenschaft, 53, 579-600. 
Schmidt, R. (1907) Wege und Ziele der Politik. Zeitschrift für Politik, 1, 1-60.

Sharp, G. (1964) Ethics and responsibility in politics. A critique of the present adequacy of Max Weber's classification of ethical systems. Inquiry 7, 1964, 304-317.

Skinner, Q. (1970) Conventions and the Understanding of Speech Acts. The Philosophical Quartely, 118-138.

Steinmetz, W. (2012) Moderne. In: U. Meier, M. Papenheim, W. Steinmetz, Semantiken des Politischen. Vom Mittelalter bis ins 20. Jahrhundert. Göttingen: Wallstein, 75120.

Treitschke, H. (1897) Politik. Vorlesungen gehalten an der Universität Berlin, I-II, ed. by Max Cornicelius. Leipizig: Hirzel.

Weber, M. (1895 [1993]) Der Nationalstaat und die Volkswirtschaftspolitik. In: MaxWeber-Gesamtausgabe I/4, eds W. J. Mommsen and R. Aldenhoff. Tübingen: Mohr, 543-574.

Weber, M. (1904 [1973]) Die 'Objektivität' sozialwissenschaftlicher und sozialpolitischer Erkenntnis. In: Gesammelte Aufsätze zur Wissenschaftslehre, Hg. Johannes Winckelmann, Tübingen: Mohr, 146-214.

Weber, M. (1917a [1973]) Der Sinn der 'Wertfreiheit' in den sozialen und ökonomischen Wissenschaften. In: Gesammelte Aufsätze zur Wissenschaftslehre, ed. Johannes Winckelmann, Tübingen: Mohr, 489-540.

Weber, M. (1917b [1988]) Wahlrecht und Demokratie in Deutschland. In: Max-WeberStudienausgabe I/15, Zur Politik im Weltkrieg, Schriften und Reden 1914-1918, eds W. J. Mommsen and G. Hübinger, Tübingen: Mohr, 155-189

Weber, M. (1918 [1988]) Parlament und Regierung im neugeordneten Deutschland. In: Max-Weber-Studienausgabe I/15, Zur Politik im Weltkrieg, Schriften und Reden 1914-1918, eds W. J. Mommsen and G. Hübinger, Tübingen: Mohr, 202-302.

Weber, M. (1919a [1994]) Politik als Beruf. In: Max-Weber-Studienausgabe I/17, Wissenschaft als Beruf, Politik als Beruf, eds W. J. Mommsen, W. Schluchter and B. Morgenbrod, Tübingen: Mohr, 35-88.

Weber, M. (1919b [1991]) Der Reichspräsident. In: Max-Weber-Studienausgabe 1/16, Zur Neuordnung in Deutschland, Schriften und Reden 1918-1920, eds W. J. Mommsen and W. Schwendtker. Tübingen: Mohr 75-77.

Weber, M. (1919c [1994]) Wissenschaft als Beruf. In: Max-Weber-Studienausgabe, Wissenschaft als Beruf, Politik als Beruf, eds W.J. Mommsen, W.Schluchter and B. Morgenbrod. Tübingen: Mohr, 1-24.

Weber, M. (1922 [1980]) Wirtschaft und Gesellschaft, ed. Johannes Winckelmann. Tübingen: Mohr.

Weber, M. (1994a) Briefe 1909-1910, Max-Weber-Gesamtausgabe, Briefe 1909-1910, eds W. J. Mommsen und M. R. Lepsius, Tübingen: Mohr.

Weber, M. (1994b) Political Writings, eds Peter Lassman and Ronald Speirs. Cambridge: Cambrige University Press.

Weber, M. (2004) The Essential Weber, ed. Sam Whimster. London: Routledge.

Weber, M. (2009) Allgemeine Staatslehre und Politik. Mit- und Nachschriften 1920, ed. G. Hübinger. Max-Weber-Gesamtausgabe III/7, Tübingen: Mohr.

Zorn, P. (1913) Politik als Staatskunst. In: Handbuch der Politik, Bd. I. Berlin: Rotschild, $1-7$. 
Kari Palonen is Professor emeritus of Political Science at the University of Jyväskylä, Finland. He is co-chair of the ECPR Standing Group Political Concepts and editor of the journal Redescriptions. He has published extensively in English and German on the concept of politics and its history, principles and practices of conceptual history, parliamentary studies as well as political thought and methodology of Max Weber.

Recent books: From Oratory to Debate. Parliamentarisation of Deliberative Rhetoric in Westminster. (Nomos 2016); A Political Style of Thinking. Essays on Max Weber (ECPR Press 2017); Debates, Rhetoric and Political Action. Practices of Textual Interpretation and Analysis, with Claudia Wiesner and Taru Haapala (Palgrave 2017); Parliamentary Thinking. Procedure, Rhetoric and Time (Palgrave 2018); Max Webers Begriffspolitik. Studien aus zwei Jahrzehnten (forthcoming Nomos 2019). 